\title{
Metode Power Control sebagai Manajemen Interferensi pada Komunikasi Device to Device
}

\section{(Power Control Method for Interference Management in Device to Device Communication)}

\author{
Anggun Fitrian Isnawati ${ }^{1}$, Solichah Larasati ${ }^{2}$, Indak Danil Mabar ${ }^{3}$
}

\begin{abstract}
Today's communication technology development has entered the 5th generation (5G), where one of the solutions offered is device to device (D2D) communication. The scheme used in this study was cooperative D2D with Mobile User Equipment (MUE) located far from the eNodeB (eNB). The D2D User Equipment (DUE) served as a relay that helped MUE to improve service quality. The effect caused by D2D communication was interference. Therefore, the power control method was used to overcome this problem. This study used three comparative simulations, namely Without Power Control, using Power Control 1, and using Power Control 2. The scheme used in Power Control 1 was a fixed power control, while Power Control 2 used an adaptive power control. Using the Cumulative Distribution Function (CDF), Power Control 1 scheme could improve SINR by $0.124 \mathrm{~dB}$ for downlink and $0.0814 \mathrm{~dB}$ for uplink. Meanwhile, Power Control 2 scheme could increase SINR by $0.0316 \mathrm{~dB}$ for downlink and 0.0627 for uplink. Based on the final results related to SINR, throughput, and CDF, the Power Control 1 method has better results than the Power Control 2 method.
\end{abstract}

Intisari-Teknologi komunikasi yang sedang berkembang saat ini sudah memasuki generasi ke-5 (5G), dengan salah satu solusi yang ditawarkan adalah komunikasi device to device (D2D). Skema yang digunakan pada makalah ini adalah cooperative D2D dengan Mobile User Equipment (MUE) yang berada jauh dari eNodeB (eNB). D2D User Equipment (DUE) berperan sebagai relay yang membantu MUE dalam meningkatkan kualitas layanan. Efek yang ditimbulkan komunikasi D2D adalah interferensi, sehingga untuk mengatasinya dilakukan metode power control. Makalah ini menggunakan tiga simulasi perbandingan, yaitu Tanpa Power Control, skema Power Control 1, dan Power Control 2. Skema yang digunakan pada Power Control 1 adalah skema fixed power control, sedangkan skema Power Control 2 menggunakan adaptive power control. Dengan menggunakan Cumulative Distribution Function (CDF), diperoleh hasil bahwa skema Power Control 1 mampu memperbaiki SINR sebesar 0,124 dB untuk downlink dan 0,0814 dB untuk uplink, sedangkan skema Power Control 2 mampu menaikkan SINR 0,0316 dB untuk downlink dan 0,0627 dB untuk uplink. Berdasarkan hasil akhir terkait SINR, throughput, dan CDF, metode Power Control 1 memiliki hasil yang lebih baik daripada metode Power Control 2.

Kata Kunci-Cooperative D2D, Power Control, SINR, Throughput.

1,2,3 Institut Teknologi Telkom Purwokerto, Jl. D.I Panjaitan No.128 Purwokerto, 53157 (telp: 0281-641629; fax: 0281-641630; e-mail: 1anggun@ittelkom-pwt.ac.id, ${ }^{2}$ laras@ittelkom-pwt.ac.id)

\section{Pendahuluan}

Perkembangan teknologi telekomunikasi saat ini sudah memasuki generasi 5G. Pada 5G ini mulai dikembangkan fiturfitur baru yang belum dimiliki oleh generasi sebelumnya. Berdasarkan data yang ada pada ITU, pada tahun 2000, pelanggan telepon bergerak seluler di Indonesia berjumlah 3,6 juta. Berdasarkan data yang sama, pada tahun 2012, angka tersebut meningkat menjadi 280 juta [1]. Peningkatan jumlah pelanggan akan menyebabkan kepadatan traffic layanan komunikasi pada Base Tranceiver Station (BTS) atau disebut evolved Node B atau eNodeB (eNB). Untuk mengatasi lonjakan kepadatan traffic komunikasi, pada teknologi 5G disediakan fitur baru, salah satunya adalah komunikasi device to device (D2D). Komunikasi D2D dianggap sebagai salah satu komunikasi yang mampu memberikan daya yang rendah, data rate yang tinggi, dan low latency [2].

Komunikasi D2D pada teknologi 5G yang akan diterapkan memungkinkan terjadinya komunikasi secara langsung antara User Equipment (UE) tanpa harus melalui eNB. Cooperative D2D merupakan salah satu skema yang melibatkan perangkat lain dalam proses pengiriman data. Cooperative menjadikan sebuah peranti (device) dapat digunakan sebagai transmitter dan relay jika beberapa peranti berada dalam area badspot [3].

Dalam suatu cakupan, ketika dua buah UE dengan fitur D2D saling berkomunikasi dan terdapat UE lain yang berkomunikasi secara konvensional, akan terjadi interferensi. Interferensi yang terjadi, baik uplink maupun downlink, menyebabkan penurunan kinerja sistem. Salah satu teknik yang diterapkan untuk mengatur interferensi adalah menggunakan metode power control [4]. Power control tidak hanya mengurangi interferensi, tetapi juga meningkatkan kapasitas sistem dan kualitas komunikasi, sehingga power control dapat digunakan sebagai salah satu teknik kunci manajemen interferensi dalam sistem komunikasi wireless. Dalam komunikasi lain, seperti komunikasi femtocell, interferensi antar pengguna terjadi pada beberapa pengguna, baik pada femtocell yang sama, maupun pada femtocell yang berbeda, tetapi berada pada channel yang sama dalam satu waktu [5]. Interferensi ini disebabkan oleh penggunaan daya pancar yang tidak proporsional oleh setiap pengguna. Pada penggunaan OFDMA, interferensi dalam suatu sel (intra-cell interference) sangat kecil, bahkan dapat diabaikan dibandingkan dengan interferensi antar sel (inter-cell interference), sehingga interferensi antar sel mendominasi kinerja sistem. Oleh karena itu, perlu adanya sistem kendali daya uplink yang diterapkan pada sisi pengguna untuk mengontrol besarnya interferensi antar sel agar interferensi 
tersebut dapat diminimalkan [6], karena tujuan power control adalah untuk memastikan daya pancar dari pemancar dapat mencapai tingkat yang cukup tinggi untuk dideteksi oleh penerima, tetapi cukup rendah untuk menghindari interferensi dengan pengguna lain.

Makalah ini menganalisis interferensi yang terjadi dengan melakukan proses manajemen interferensi saat komunikasi sedang berlangsung pada frekuensi yang sama. Proses manajemen interferensi yang diusulkan menggunakan metode power control menggunakan skema cooperative $\mathrm{D} 2 \mathrm{D}$ dengan cara mengatur daya pancar dari eNB. Dengan adanya metode power control, nilai Quality of Service (QoS) dapat terpenuhi, yaitu memperbaiki nilai Signal to Interference plus Noise Ratio (SINR). Penggunaan metode power control pada komunikasi D2D jenis pair to pair mampu memperbaiki nilai throughput sebesar 51,41 Mbps seperti pada penelitian sebelumnya [7]. Referensi [8]-[9] mambahas jenis interferensi pada jaringan two-tier berbasis 5G, yaitu interferensi co-tier dan cross-tier, dengan cross-tier memiliki interferensi yang lebih besar. Teknologi terdahulu juga sudah menggunakan komunikasi D2D, yaitu pada komunikasi Wi-Fi direct, tetapi untuk jarak yang dekat [10].

\section{Metodologi}

\section{A. Skema Metode Power Control}

Skema yang digunakan pada makalah ini ada dua, yaitu Power Control 1, yang menggunakan skema fixed power control, dan Power Control 2, yang menggunakan skema adaptive power control:

1) Skema Fixed Power Control: Skema ini melakukan penurunan daya pancar penginterferensi sebesar $1 \mathrm{~dB}$ apabila nilai penginterferensi sama.

2) Skema Adaptive Power Control: Skema ini hanya melakukan penurunan daya pada penginterferensi dengan jarak tertentu yang sudah ditentukan.

\section{B. Skema Interferensi pada Jaringan Seluler}

Komunikasi dapat melayani setiap pengguna, baik dalam keadaan diam ataupun bergerak. Istilah seluler berarti cakupan berdasarkan beberapa sel (cell) [11]. Sel yang memiliki traffic tinggi memiliki ukuran sel yang kecil, sedangkan sel yang memiliki kepadatan rendah memiliki ukuran sel yang besar [11]. Frequency reuse adalah pengulangan frekuensi yang sama pada sel lain. Semakin besar reuse, semakin bagus kinerja jaringan, tetapi kapasitas sel yang dapat dilayani dalam satu eNB sangat kecil [12].

Dalam simulasi ini, digunakan satu sel makro (single macrocell) yang di dalamnya terdapat Cellular User Equipment (CUE) dan D2D pair. Skenario simulasi dilakukan pada sisi uplink dan downlink. Pada skenario downlink, QoS diamati pada sisi penerima, yaitu CUE, sedangkan pada skenario uplink, QoS diamati pada sisi pemancar, yaitu eNB. Pada masingmasing skenario dikenakan dua metode analisis, yaitu analisis tanpa metode power control dan dengan metode power control.

Pada skema downlink, eNB memancarkan sinyal broadcast downlink ke CUE, seperti ditunjukkan pada Gbr. 1. Karena

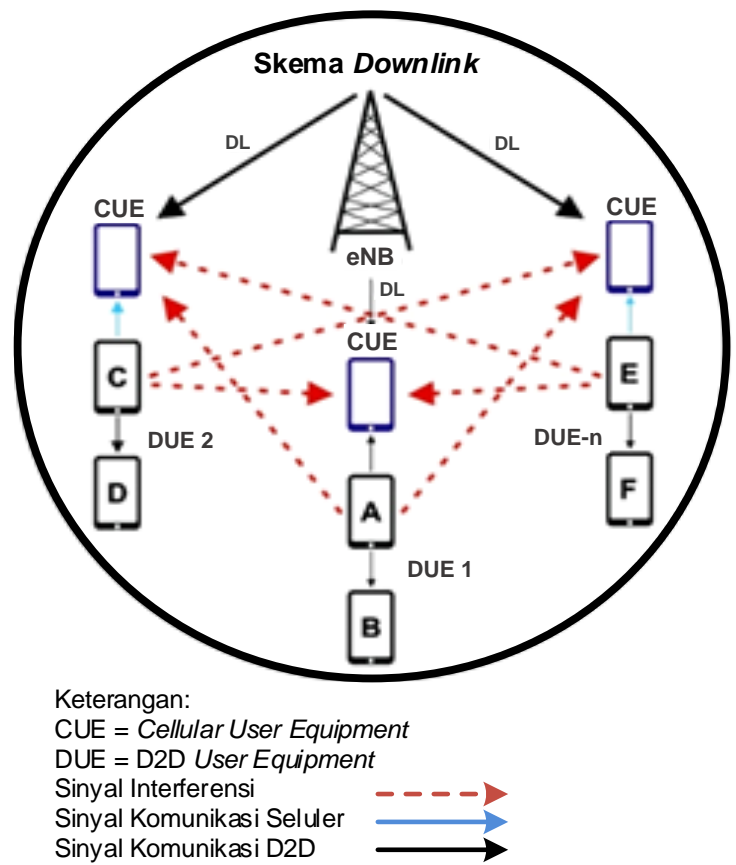

Gbr. 1 Skema transmisi daya pada periode downlink.

jarak CUE yang jauh, skema cooperative D2D dibantu dengan perangkat Device-to-Device User Equipment (DUE). Pada skema ini terdapat tiga CUE dan $n$ perangkat D2D pair, dengan setiap pasang D2D sedang berkomunikasi satu sama lain. Sinyal downlink dari eNB terkena interferensi dari Transmitter User Equipment (TUE) yang sedang berkomunikasi dengan Receiver User Equipment (RUE). Pada skenario ini, diasumsikan semua perangkat D2D pair menggunakan frequency resource yang sama dengan CUE dan diasumsikan juga antar D2D pair saling terisolasi, sehingga tidak menginterferensi satu sama lain.

Skenario uplink menggunakan beberapa D2D pair dan tiga buah CUE dengan skema cooperative D2D. Pada skenario ini, perangkat CUE melakukan transmisi uplink ke eNB. Proses transmisi tersebut akan terinterferensi oleh perangkat TUE dan perangkat D2D pair yang sedang melakukan transmisi ke perangkat pasangannya. Pada skenario ini, nilai SINR pada eNB dipelajari untuk melihat nilai SINR tersebut sesuai dengan nilai rata-rata atau tidak. Pada skenario ini juga terjadi interferensi yang disebabkan oleh CUE yang sedang melakukan transmisi uplink dan menimbulkan interferensi terhadap RUE dari D2D pair pada daerah cakupan eNB seperti ditunjukkan pada Gbr. 2

\section{Perencanaan Sistem Seluler}

Komunikasi seluler dapat melayani setiap pengguna yang diam ataupun bergerak. Cakupan suatu sel dapat merepresentasikan cakupan suatu Base Station (BS). Pada simulasi ini, digunakan parameter sistem jaringan seluler seperti yang ditunjukkan pada Tabel I.

\section{Metode Power Control}

Metode power control merupakan salah satu metode yang digunakan untuk mengurangi interferensi yang terjadi. Metode 


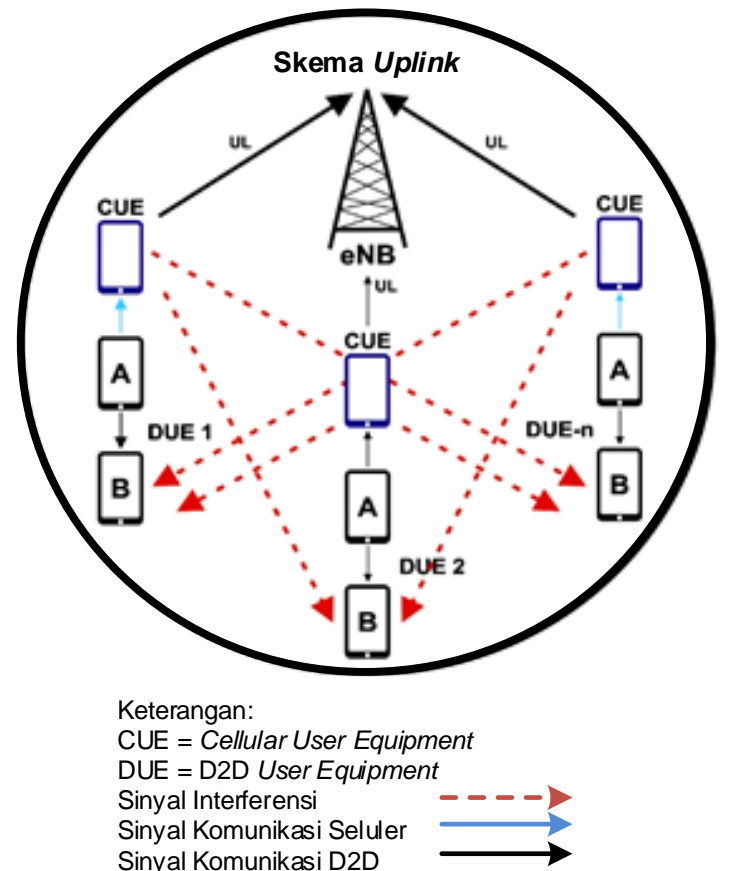

Gbr. 2 Skema transmisi daya pada periode uplink.

TABEL I

PARAMETER SISTEM JARINGAN SELULER

\begin{tabular}{|c|c|}
\hline Parameter & Nilai \\
\hline Radius macrocell & $1.000 \mathrm{~m}$ \\
\hline Radius DUE (D2D terhadap D2D-R) & $100 \mathrm{~m}$ \\
\hline Daya transmisi eNB (maksimal) & $46 \mathrm{~dB}$ \\
\hline Daya transmisi CUE (maksimal) & $23 \mathrm{~dB}$ \\
\hline Central carrier & $1.800 \mathrm{MHz}$ \\
\hline Bandwidth & $10 \mathrm{MHz}$ \\
\hline Noise thermal & $-174 \mathrm{dBm} / \mathrm{Hz}$ \\
\hline Posisi CUE terhadap eNB & 100 s.d. $600 \mathrm{~m}$ \\
\hline Posisi D2D-T terhadap eNB & 600 s.d. $900 \mathrm{~m}$ \\
\hline
\end{tabular}

power control membantu dalam beberapa fungsi, seperti manajemen interferensi, manajemen daya, dan manajemen ketersambungan. Metode ini mampu meningkatkan efisiensi penggunaan spektrum dan kualitas layanan [7]. Power control mengatur besar kecilnya daya yang dipancarkan oleh eNB yang akan disebarkan ke suatu perangkat (seperti perangkat D2D) terhadap perangkat lain (seperti perangkat telepon seluler) yang berada di dekatnya.

\section{E. Plotting Perangkat dan Perhitungan Jarak}

Pada simulasi ini dilakukan pembangkitan perangkat jaringan seluler seperti eNB yang secara otomatis dibangkitkan pada koordinat $(0,0)$ dan CUE dibangkitkan secara acak. Koordinat pada pembangkitan perangkat CUE sebagai berikut ditentukan sebagai berikut.

$$
\begin{aligned}
& \text { Koordinat CUE } x=\text { Radius } x \cos (a) \\
& \text { Koordinat CUE } x=\text { Radius } x \sin (a) .
\end{aligned}
$$

Besar radius dari eNB untuk perangkat MUE adalah sejauh 400-800 m, sedangkan radius dari D2D-T sejauh 700-800 m dari eNB. Setelah pembangkitan perangkat CUE, dilakukan perhitungan jarak untuk menghitung nilai sinyal broadcast yang diterima perangkat CUE dan sinyal interferensi yang ditimbulkan oleh perangkat D2D. Jarak dapat dihitung sebagai berikut.

$$
\begin{aligned}
& \text { Jarak CUE }-e N B(m) \\
& =\sqrt{\left(e N B_{x}-C U E_{x}\right)^{2}+\left(e N B_{y}-C U E_{y}\right)^{2}} \\
& \operatorname{Jarak} D 2 D R-e N B(m) \\
& =\sqrt{\left(e N B_{x}-D 2 D R_{x}\right)^{2}\left(e N B_{y}-D 2 D R_{y}\right)^{2}} \\
& J a r a k D 2 D T-C U E(m) \\
& =\sqrt{\left(C U E_{x}-D 2 D T_{x}\right)^{2}+\left(C U E_{y}-D 2 D T_{y}\right)^{2}} .
\end{aligned}
$$

Selanjutnya, nilai pathloss dihitung menggunakan (6) dan (7). Pathloss dipengaruhi oleh kontur bumi, medium propagasi, dan jarak antara pemancar dengan penerima. Pathloss biasanya mencakup kerugian propagasi dari gelombang radio [13]. Pathloss jalur antara UE dan eNB dihitung sebagai berikut [7].

$$
P L_{\text {cell link }}=128,1+37,6(\log (d[\mathrm{~km}])
$$

sedangkan pathloss yang terjadi pada D2D link (jalur antar UE) dihitung sebagai berikut [7]:

$$
P L_{\text {D2Dlink }}=148+40(\log (d[k m])
$$

dengan

$$
\begin{aligned}
& P L_{\text {cell link }}=\text { pathloss seluler link }(\mathrm{dB}) \\
& P L_{\text {D2Dlink }}=\text { pathloss } \mathrm{D} 2 \mathrm{D} \text { link }(\mathrm{dB}) \\
& =\quad \text { jarak antara kedua perangkat yang dilakukan } \\
& \begin{aligned}
\text { perhitungan pathloss }(\mathrm{km}) .
\end{aligned}
\end{aligned}
$$

Setelah nilai pathloss diperoleh, dibutuhkan perhitungan nilai daya yang diterima oleh perangkat penerima $(S)$. Nilai daya yang diterima dihitung sebagai berikut.

$$
S(d B m)=P_{T}(d B m)-\text { Pathloss }(d B) .
$$

Perhitungan nilai SINR untuk uplink dan downlink adalah sebagai berikut [3].

$$
\begin{aligned}
& \operatorname{SINR}_{M U E_{k}}^{D L}=\frac{S_{\text {eNB.MUE }}}{\sum_{1}^{k}\left(I_{D 2 D T_{k} \cdot M U E}\right)+N} \\
& \operatorname{SINR}_{e N B_{k}}^{U L}=\frac{S_{M U E, e N B}}{\sum_{1}^{k}\left(I_{D 2 D R_{k} \cdot M U E}\right)+N}
\end{aligned}
$$

dengan $S I N R_{M U E_{k}}^{D L}$ adalah SINR MUE pada periode downlink dan $S I N R_{e N B_{k}}^{U L}$ merupakan SINR eNB pada periode uplink.

Besar nilai SINR pada sisi penerima dari pasangan node yang diamati dapat dihitung menggunakan (11) [3].

$$
S I N R=\frac{P}{I+N}
$$

dengan $P$ adalah daya terima dalam watt, $I$ adalah daya interferensi yang terjadi dalam watt, dan $N$ adalah daya noise dalam watt. Metode power control bekerja dengan cara mengatur besarnya nilai daya pancar yang tergantung pada $P$. Pada suatu kondisi ketika perangkat D2D berbagi sumber daya pada kanal downlink, maka SINR dari CUE- $k$ dapat dihitung dengan (12) [3]. 


$$
\operatorname{SINR}_{C U E_{k}}^{D L}=\frac{P_{B S, C U E_{k}} G_{B S, C U E_{k}}}{r d(k) P_{T U E_{k}} C U E_{k} G_{T U E_{k}} C U E_{k}+N} .
$$

Untuk mencari nilai SINR pada D2D RUE (DRUE) pada sumber daya kanal- $k$, dilakukan perhitungan berikut.

$$
\operatorname{SINR}_{R U E_{k}}^{D L}=r d(k) \frac{P_{T U E_{k}, R U E_{k}} G_{T U E_{k}, C U E_{k}}}{P_{B S, R U E_{k}} G_{B S, R U E_{k}}+N} .
$$

Kondisi ketika pasangan perangkat D2D berbagi sumber daya dengan pengguna seluler pada kanal uplink oleh berbagai uplink resource dihitung sebagai berikut [3].

$$
\begin{aligned}
& \operatorname{SINR}_{B S}^{U L}=\frac{\sum_{k=1}^{m}{ }^{{ }{ }_{C U E_{k}}{ }^{B S} G_{C U E_{k}, B S}}}{\left(r u(k) P_{T U E_{k} C U E_{k} G_{T U E_{k}} C U E_{k}+N}\right.} \\
& S_{I N R_{B S}^{U L}}^{U L}=r u(k) \frac{P_{C U E_{k}, R U E_{k}} G_{T U E_{k}} R U E_{k}}{P_{C U E_{k} R U E_{k}} G_{C U E_{k} R U E_{k}}+N}
\end{aligned}
$$

dengan

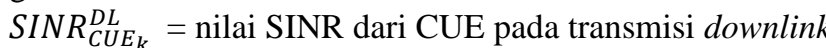

$$
\begin{aligned}
& S I N R_{R U E_{k}}^{D L}=\text { nilai SINR dari RUE pada transmisi downlink } \\
& S I N R_{B S}^{U L}=\text { nilai SINR dari BS pada transmisi uplink } \\
& \operatorname{SINR}_{B S_{k}}^{U L} \quad=\text { nilai SINR pada RUE pada transmisi uplink } \\
& N \quad=\text { noise }(\mathrm{W}) \\
& P_{B S, C U E_{k}} \quad=\text { daya pancar BS ke pengguna CUE (W) } \\
& P_{C U E_{k}, B S}=\text { daya pancar dari pengguna CUE ke BS }(\mathrm{W}) \\
& P_{T_{U E}, R U E_{k}}=\text { daya pancar dari pengguna D2D (TUE) ke } \\
& \text { pengguna D2D (RUE) (W) } \\
& P_{T U E_{k} B S}=\text { daya pancar dari pengguna D2D (TUE) ke BS } \\
& \text { (W) } \\
& P_{B S, R U E_{k}}=\text { daya pancar dari BS ke pengguna } \mathrm{D} 2 \mathrm{D} \\
& \text { (RUE) (W) } \\
& P_{\text {TUE }_{k} C U E_{k}}=\text { daya pancar dari pengguna D2D (TUE) ke } \\
& \text { pengguna CUE (W) } \\
& P_{B S, R U E_{k}} \quad=\text { daya pancar dari BS ke pengguna D2D } \\
& \text { (RUE) (W) } \\
& r d(k)=\text { indikator kesamaan penggunaan resource } \\
& \text { downlink }
\end{aligned}
$$

Kualitas layanan QoS juga dipengaruhi oleh nilai throughput yang merupakan laju data aktual dari informasi yang ditransfer. Terdapat dua tipe throughput, yaitu uplink dan downlink [14]. Nilai throughput dapat dihitung sebagai berikut [7].

$$
C=B \times \log _{2}(1+\operatorname{SINR})
$$

dengan $B$ adalah nilai bandwidth dalam satuan $\mathrm{Hz}$.

\section{HASIL DAN PEMBAHASAN}

\section{A. Analisis Simulasi Skema 1 Periode Downlink}

Percobaan ini menggunakan perbandingan dua skema yang berbeda, yakni dengan membandingkan dan memilih

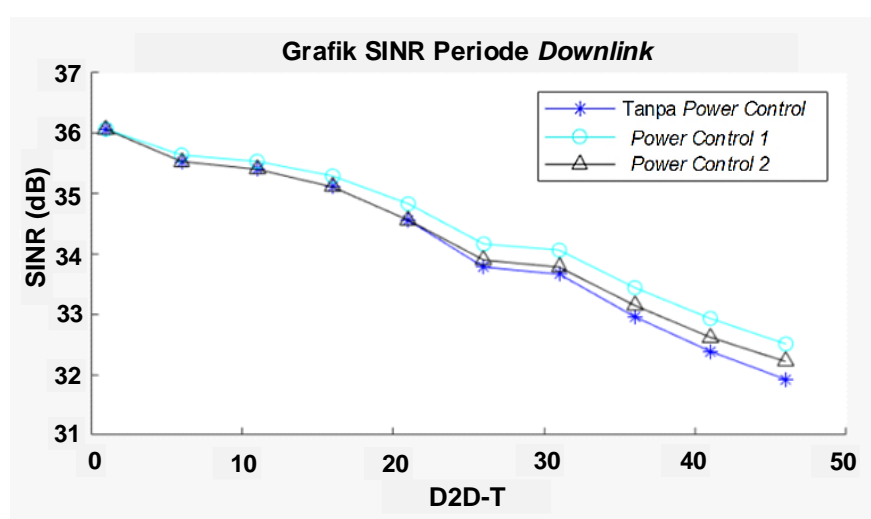

Gbr. 3 Grafik nilai SINR (dB) pada MUE terhadap jumlah D2D-T.

TABEL II

Hasil Simulasi SKema 1 PeRIOde DOWNLINK PADA MUE

\begin{tabular}{|c|l|c|c|}
\hline No. & $\begin{array}{c}\text { Skema Manajemen } \\
\text { Interferensi }\end{array}$ & $\begin{array}{c}\text { SINR } \\
\text { (dB) }\end{array}$ & $\begin{array}{c}\text { Throughput } \\
\text { (Mbps) }\end{array}$ \\
\hline 1 & Tanpa Power Control & 33,49 & 102,14 \\
\hline 2 & Power Control 1 & 33,86 & 102,45 \\
\hline 3 & Power Control 2 & 33,67 & 102,29 \\
\hline
\end{tabular}

manajemen yang lebih baik untuk digunakan. Pada percobaan pertama, dilakukan proses analisis dengan skema periode downlink. Dalam simulasi pada percobaan ini hanya ada satu perangkat CUE yang melakukan panggilan konvensional dan dilakukan penambahan perangkat D2D sampai dengan lima puluh perangkat D2D. Dari hasil simulasi, didapatkan grafik nilai SINR dan throughput menurun pada CUE, sebagaimana ditunjukkan pada Gbr. 3. Simulasi skema ini dilakukan sebanyak lima kali percobaan dengan masing-masing simulasi mengambil lima sampel penginterferensi.

Pada percobaan skema periode downlink ini dihasilkan data perbandingan nilai rata-rata yang didapat dari SINR dan throughput dengan menggunakan tiga skema manajemen interferensi, yaitu: 1) Tanpa Power Control; 2) menggunakan manajemen interferensi Power Control 1; dan 3) menggunakan manajemen interferensi Power Control 2.

Hasil simulasi skema 1 disajikan pada Gbr. 3 dan Tabel II. Gbr. 3 menunjukkan bahwa dengan meningkatnya jumlah perangkat D2D-T, nilai SINR dan throughput pada CUE akan mengalami penurunan. D2D Transmiter (D2D-T) adalah penginterferensi utama yang mengakibatkan nilai SINR dari CUE menurun. Tabel II menunjukkan bahwa nilai yang diperoleh dari rata-rata SINR Tanpa Power Control adalah $33,49 \mathrm{~dB}$. Setelah dilakukan manajemen interferensi menggunakan Power Control 1, nilai rata-rata SINR naik menjadi 33,86 dB atau meningkat sebesar 0,37 dB, sedangkan jika digunakan Power Control 2, nilai rata-rata SINR menjadi 33,67 dB atau meningkat sebesar 0,19 dB. Hal ini menunjukkan bahwa nilai rata-rata SINR manajemen interferensi Power Control 1 lebih tinggi daripada Power Control 2. Peningkatan juga terjadi pada nilai throughput, dengan peningkatan yang tertinggi juga diperoleh oleh Power Control 1, dengan nilai throughput 102,45 Mbps atau meningkat sebesar 0,31 Mbps. Sementara itu, metode Power Control 2 memperoleh nilai throughput sebesar 102,29 Mbps atau meningkat sebesar 0,15 


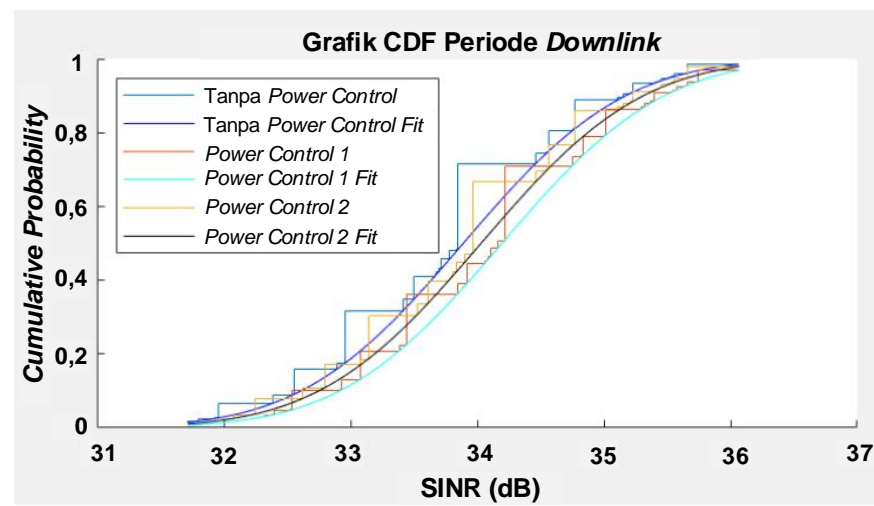

Gbr. 4 Grafik CDF SINR dari CUE periode downlink dengan fitting.

Mbps. Secara keseluruhan, metode Power Control 1 memiliki manajemen interferensi lebih baik dibanding metode Power Control 2.

Nilai grafik dari skema yang dihasilkan, yaitu nilai SINR dan nilai CUE, dapat dilihat juga menggunakan nilai Cumulative Distribution Function (CDF), seperti ditunjukkan pada Gbr. 4. Nilai skema CDF yang dihasilkan pada Gbr. 4 tersebut dapat ditunjukkan berdasarkan parameter SINR, yakni bahwa nilai SINR mencapai $32 \mathrm{~dB}$ untuk skema Tanpa Power Control 51,49\%, sedangkan Power Control 1 dan Power Control 2 mampu memperbaiki nilai SINR yang didapat sebelumnya. Dengan metode Power Control 1, probabilitas nilai SINR < 32 dB sebesar 39,46\% dan menggunakan metode Power Control 2, probabilitas mencapai $11,45 \%$. Hal ini menunjukkan bahwa metode Power Control 1 mampu melakukan manajemen interferensi lebih baik dibandingkan dengan metode Power Control 2 maupun dibandingkan dengan skema Tanpa Power Control.

\section{B. Analisis Simulasi Skema 2 Periode Uplink}

Simulasi skema kedua dilakukan pada periode uplink. Analisis pada skema 2 ini dilakukan berdasarkan interferensi yang terjadi saat proses transmisi ke eNB. Selain MUE melakukan transmisi skema uplink, interferensi juga terjadi akibat perangkat D2D-R yang sedang melakukan transmisi terhadap perangkat D2D-T. Grafik nilai SINR yang diperoleh ditunjukkan pada Gbr. 5.

Berdasarkan Gbr. 5, diketahui bahwa nilai SINR eNB semakin menurun seiring dengan meningkatnya jumlah penginterferensi. Simulasi ini dilakukan sebanyak lima kali percobaan dengan peningkatan perangkat D2D sampai lima puluh perangkat sebagai interferensi. Hasil analisis skema 2 periode uplink dari nilai keseluruhan disajikan pada Tabel III.

Nilai SINR dan throughput yang diperoleh pada periode uplink sama seperti pada periode downlink, yaitu nilai yang dihasilkan menggunakan metode manajemen interferensi power control mengalami peningkatan. Pada SINR, nilai hasil rata-rata yang tertinggi adalah manajemen interferensi menggunakan metode Power Control 1, yaitu 15,69 dB, meningkat sebesar $0,24 \mathrm{~dB}$ dibandingkan dengan nilai SINR pada skema Tanpa Power Control, sedangkan nilai rata-rata yang didapat pada metode Power Control 2 sebesar 15,58 dB, yaitu meningkat $0,13 \mathrm{~dB}$ dari skema Tanpa Power Control.

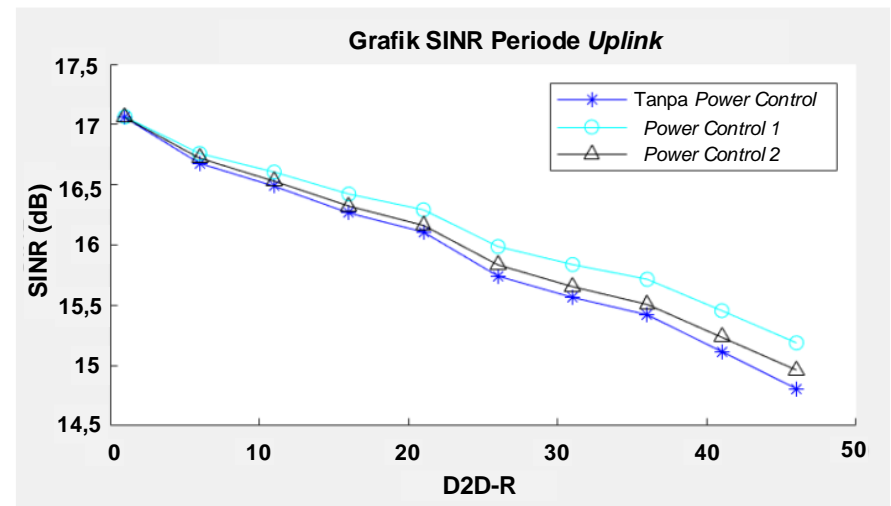

Gbr. 5 Grafik nilai SINR eNB terhadap jumlah D2D-R.

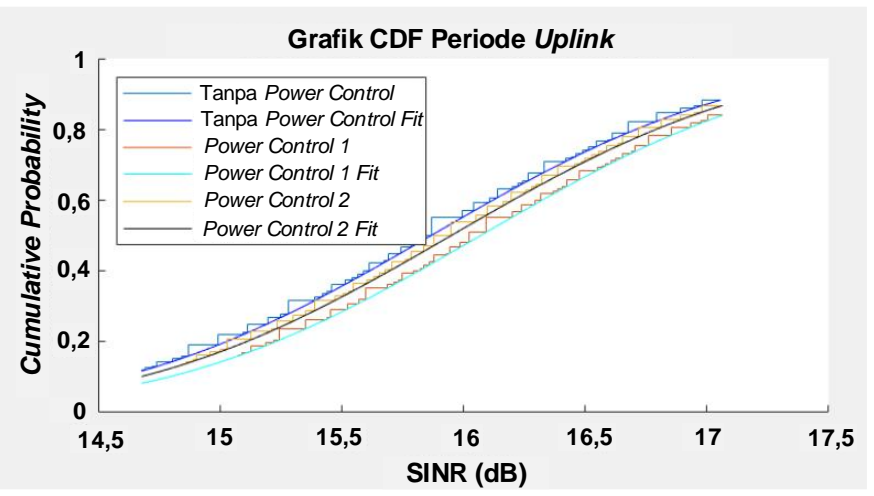

Gbr. 6 Grafik CDF SINR dari MUE periode uplink dengan fitting.

TABEL III

HASIL SIMUlasi SKEMA 2 PERIODE UPLINK PADA ENB

\begin{tabular}{|c|l|c|c|}
\hline No. & $\begin{array}{c}\text { Skema Manajemen } \\
\text { Interferensi }\end{array}$ & $\begin{array}{c}\text { SINR } \\
(\mathbf{d B})\end{array}$ & $\begin{array}{c}\text { Throughput } \\
\text { (Mbps) }\end{array}$ \\
\hline 1 & Tanpa Power Control & 15,45 & 80,73 \\
\hline 2 & Power Control 1 & 15,69 & 81,17 \\
\hline 3 & Power Control 2 & 15,58 & 80,96 \\
\hline
\end{tabular}

Dengan meningkatnya nilai SINR, akan diperoleh peningkatan pada nilai throughput. Peningkatan tertinggi terjadi ketika digunakan metode Power Control 1, dengan nilai throughput sebesar 81,17 Mbps, atau meningkat 0,44 Mbps, sedangkan Power Control 2 menghasilkan throughput sebesar 80,96 Mbps, meningkat 0,23 Mbps dibanding tanpa manajemen interferensi, yaitu sebesar 80,73 Mbps. Oleh karena itu, pada periode uplink, manajemen interferensi yang paling efektif adalah skema Power Control 1. Grafik CDF periode uplink ditunjukkan pada Gbr. 6.

Gbr. 6 menunjukkan grafik nilai CDF dari SINR pada eNB. Setelah dilakukan fitting curve, probabilitas nilai SINR pada eNB $\leq 16 \mathrm{~dB}$ untuk skema Tanpa Power Control adalah sebesar 0,5514 dan setelah menggunakan Power Control 1 dan Power Control 2 nilai probabilitasnya menjadi, berturut-turut, 0,47 dan 0,5208. Maka, dalam periode uplink, skema Power Control 1 mampu memperbaiki SINR sebesar 0,0814 dan skema Power Control 2 memperbaiki SINR sebesar 0,0306.

\section{KESIMPULAN}

Hasil data yang diperoleh pada makalah ini menggunakan parameter jarak antar perangkat, pathloss, dan besarnya daya 
transmisi. Analisis dilakukan terhadap parameter QoS, meliputi nilai SINR, throughput, dan hasil grafik CDF. Dari analisis hasil percobaan, dapat disimpulkan bahwa semakin banyak jumlah penginterferensi, nilai QoS dari SINR dan throughput akan mengalami penurunan. Manajemen interferensi menggunakan metode power control mampu memperbaiki dan meningkatkan nilai SINR baik pada periode downlink maupun periode uplink. Analisis pada sistem simulasi perbandingan ini diperoleh berdasarkan grafik CDF yang menunjukkan bahwa nilai kumulatif probabilitas metode Power Control 1 dan Power Control 2 mampu memperbaiki nilai SINR, baik untuk periode uplink maupun periode downlink, jika dibandingkan dengan metode Tanpa Power Control. Berdasarkan hasil keseluruhan terkait SINR, throughput, dan CDF, maka metode Power Control 1 memiliki perbaikan nilai yang lebih efektif dan lebih baik daripada skema metode Power Control 2.

\section{UCAPAN TERIMA KASIH}

Terima kasih disampaikan kepada LPPM Institut Teknologi Telkom Purwokerto atas pendanaan Hibah Penelitian Internal yang dapat digunakan untuk membiayai publikasi ini.

\section{REFERENSI}

[1] K. Ariansyah, "Proyeksi Jumlah Pelanggan Telepon Bergerak Seluler di Indonesia," Buletin Pos Telekom., Vol. 12 No. 2, hal. 151-166, Jun. 2014

[2] U.K. Usman, "Mengenal Teknologi 5G," Proc. CITISEE, 2017, hal. 345348.

[3] A. Abadi, "Manajemen Interferensi dengan Menggunakan Power Control untuk Komunikasi Device-To-Device (D2D) dalam Jaringan Komuniasi Seluler," Skripsi, Universitas Lampung, Bandar Lampung, Indonesia, 2017.

[4] I.A. Lestari, A. Nurdin, dan Asriyadi, "Analisis Manajemen Interferensi Jaringan Uplink 4G-LTE dengan Metode Innerloop Power Control di PT. Telkomsel," Proc. SNATIF, 2017, hal. 383-388.
[5] I.W. Mustika, K. Yamamoto, H. Murata, dan S. Yoshida, "Potential Game Approach for Self-Organized Interference Management in Closed Access Femtocell Networks," IEEE $73^{\text {rd }}$ Veh. Technol. Conf. (VTC Spring), 2011, hal. 1-5.

[6] Z. Li, Z. Jiang, Y. Wang, dan D. Yang, "A Modified Power Control Scheme in OFDMA Uplink," $4^{\text {th }}$ Int. Conf. Wireless Commun., Netw. Mobile Comput. (WiCOM'08), 2008, hal. 1-5.

[7] M.P. Pamungkas, "Analisis Manajemen Interferensi Komunikasi Deviceto-Device menggunakan Metode Power Control," Tugas Akhir S1, Universitas Muhammadiyah Yogyakarta, Yogyakarta, Indonesia, 2017.

[8] D. Fauzia, "Manajemen Interferensi pada Transmisi Downlink Jaringan Selular Two-Tier Berbasis 4G LTE-Advenced dengan Menggunakan Metode Power Control," Skripsi, Universitas Lampung, Bandar Lampung, Indonesia, Feb. 2017.

[9] A.F. Isnawati dan M.A. Afandi, "Game Theoretical Power Control in Heterogeneous Network," $9^{\text {th }}$ Int. Conf. Inf. Commun. Technol. (ICoICT), 2021, hal. 149-154.

[10] B.A.P. Setiyono, E.S. Pramukantoro, dan K. Amron, "Pengembangan Infrastruktur Komunikasi Multigroup pada Wifi Direct," J. Teknol. Inf Ilmu Komput. (JTIIK), Vol. 4 No. 1, hal. 52-61, Des. 2017.

[11] F. Al-Kausar, "Optimalisasi Jaringan Berdasarkan Drive Test," Skripsi, Universitas Indonesia, Depok, Indonesia, Des. 2009.

[12] F. Riski, R.P. Astuti, dan Y.S. Rohmah, "Analisis Perancangan Jaringan Long Term Evolution (LTE) di Wilayah Kota Banda Aceh dengan Fractional Frequency Reuse sebagai Managemen Interferensi," e-Proc. Eng., Vol. 1, No. 1, hal. 104-110, Des. 2014.

[13] A. Hikmaturokhman, E. Wahyudi, dan H. Sulaiman, "Analisa Pengaruh Interferensi terhadap Availability pada Jaringan Transmisi Microwave Menggunakan Software Pathloss," J. ECOTIPE, Vol. 1, No. 2, hal. 8-17, Okt. 2014.

[14] S.G.Y.P. Putra, P.K. Sudiarta, dan G. Sukadarmika, "Analisis Hasil Drive Test Menggunakan Software Genex Probe dan Genex Assistant," $J$ SPEKTRUM, Vol. 5, No. 1, hal. 116-122, Jun. 2018. 